\title{
Behavioral effects of essential oil of Citrus aurantium L. inhalation in rats
}

\author{
Mariana P. Leite, ${ }^{1}$ Jaime Fassin Jr., ${ }^{1}$ Eliane M. F. Baziloni, ${ }^{1}$ Reinaldo N. Almeida, ${ }^{2}$ Rita \\ Mattei, *,1 José R. Leite ${ }^{1}$
}

${ }^{1}$ Departamento de Psicobiologia, Universidade Federal de São Paulo, Rua Botucatu 862, Ed. Ciências Biomédicas, 04023-062 São Paulo-SP, Brazil,

${ }^{2}$ Laboratório de Tecnologia Farmacêutica, Universidade Federal da Paraíba, Caixa Postal 5009, 58051-970

João Pessoa-PB, Brazil

\begin{abstract}
RESUMO: "Efeitos comportamentais em ratos após inalação do óleo essencial de Citrus aurantium L.". O óleo essencial de laranja (OEL) e seus constituintes obtidos da Citrus aurantium L. (Rutaceae) têm despertado interesse pela sua ação sedativa e relaxante. No presente estudo, ratos previamente expostos à inalação do OEL nas concentrações de $1,0 \% ; 2,5 \%$ e $5,0 \%, \mathrm{p} / \mathrm{v}$, durante 7 minutos em caixas de acrílico, foram avaliados em dois modelos de ansiedade: labirinto em cruz elevado (LCE) e campo aberto. O OEL na concentração de $2,5 \%$ aumentou tanto o tempo de permanência dos animais nos braços abertos do LCE, como o tempo de interação social ativa no campo aberto, tendo sido superior ao grupo padrão diazepam $(1,5 \mathrm{mg} / \mathrm{kg})$ ip. A diminuição do grau de emocionalidade dos animais observada nos dois modelos experimentais sugere uma possível ação central, o que está de acordo com o perfil fitoquímico do óleo em estudo o qual mostrou a presença de limoneno $(96,24 \%)$ e mirceno $(2,24 \%)$, constituintes com comprovada atividade depressora sobre o sistema nervoso central.
\end{abstract}

Unitermos: Óleo essencial, Citrus aurantium, Rutaceae, óleo de laranja, ansiedade, inalação, labirinto em cruz elevado.

\begin{abstract}
The orange essential oil (OEO) and its components obtained from Citrus aurantium L. (Rutaceae) has been attracting interest due to its sedative and relaxing actions. In the present study, rats previously exposed to OEO at the concentrations of $1.0 \% ; 2.5 \%$ and $5.0 \%$, w/w, by inhalation during 7 minutes in acrylic boxes were evaluated in two anxiety models: elevated plus maze (EPM) and open-field. The OEO at the concentration of $2.5 \%$ increased both the time of the animals in the open arms of the EPM and the time of active social interaction in the open-field being longer than that of the diazepam group $(1.5 \mathrm{mg} / \mathrm{kg}$ i.p). In conclusion, the decrease in the level of emotionality of the animals observed in the two experimental models suggests a possible central action, which is in agreement with the phytochemical profile of the oil under study, since it showed the presence of limonene (96.24\%) and mircene (2.24\%), components with a wellknown depressant activity on the central nervous system.
\end{abstract}

Keywords: Essential oil, Citrus aurantium, Rutaceae, orange oil, anxiety, inhalation, plusmaze.

\section{INTRODUCTION}

The medicinal use of essential oils has been known since the early times (Umezu et al., 2002). Popularly, they are used in the control of emotions and mood, for their sedative, anxiolytic (Lehrner et al., 2000), antidepressant effects (Komori et al., 1995a; De-Souza et al., 2006), and anticonvulsant (Viana et al., 2000; Sousa et al., 2007) among others (Oliveira et al., 2006; Ferronatto et al., 2007; Oliveira et al., 2007; Barbosa-Filho et al., 2008; Sousa et al., 2008). Some studies suggest that they act by modulating the central neurotransmission (Komiya et al., 2006). A relation between the perception of odors and the emotional behavioral response has been suggested, showing neuroanatomical correlation (orbitofrontal cortex, amygdala, pyriform cortex, and insular and anterior cingulate cortex) between emotion and smell (Pollatos et al., 2007). Clinical studies suggest that the exposure to the inhalation of various kinds of essential oils is effective in reducing psychological stress, anxiety state, as well as the levels of cortisol in hypertensive patients (Hwang, 2006). The positive effects of essential oils on anxiety and depression symptoms have aroused interest, since they might be an alternative to synthetic substances which induce various side effects such as sedation, memory alterations and interaction with other drugs (Gumnick and Nemeroff, 2000). Among the aromatic plants, Citrus aurantium L. 
(Rutaceae) is indicated in the popular medicine as an alternative in the treatment of anxiety, which suggests a possible central action (Pultrini et al., 2006). The orange essential oil (OEO) showed a depressant activity on the central nervous system (CNS) after the intraperitoneal administration to mice (Carvalho-Freitas and Costa, 2002). Such response might be attributed to a specific or synergetic effect of the many components present in the OEO, among which we should mention limonene and mircene, which have an attested action on the CNS (Pultrini et al., 2006). Studies carried out with rats, evaluated in depression models, provide evidence that citrus essences act by strengthening the immune response as well as potentiating the anti-depressant effects of the imipramine (Komori et al., 1995b), that were also observed in clinical studies with patients with depression (Komori et al., 1995a). In this sense, considering the relation between smell and emotions, and the strong effect of fragrances on emotional states (Van Toller, 1988), the present study aimed at assessing a possible anxiolytic effect on rats exposed to the inhalation of OEO, evaluated in experimental models of anxiety. In order to do so, we considered the following aspects: different behavioral parameters in the openfield, the number of entries in the open arms and the time spent in each arm of the elevated plus maze (EPM), time of active social interaction (TSI) and the determination of the phytochemical profile of the essential oil.

\section{MATERIAL AND METHODS}

\section{Animals}

Were used 3-4 months old male Wistar rats weighing 300-350 g. The animal laboratory of the Department of Psychobiology - UNIFESP supplied the animals. They were kept in polypropylene cages $(32 \mathrm{x}$ $40 \times 18 \mathrm{~cm}), 4$ animals per cage, in rooms with 12-hour light/dark cycles (lights on at 6:00 a.m.). The temperature was kept at $20 \pm 2{ }^{\circ} \mathrm{C}$, and water and food were provided ad libitum. All tests were carried out between 1:00 and 5:00 p.m. All procedures were conducted in accordance with the animal scientific procedures. The Committee of Ethics in Research of UNIFESP approved the experimental protocol (CEP: $\left.\mathrm{N}^{\circ} 0700 / 06\right)$.

\section{Chemicals}

The OEO was supplied from International Flavors and Fragrance (IFF) Ltda., São Paulo. It was obtained from the orange peel, C. aurantium. Diazepam was acquired from Roche.

\section{Analysis of the essential oil}

The OEO was analyzed by gas chromatography. The quantification of the oil constituents was calculated from the GC with a flame ionization detector. CG analysis was carried out on an Agilet-HP 6890 gas chromatograph with a FID detector and a COV-1 capillary column ( $30 \mathrm{~m}$ x $0.25 \mathrm{~mm}$ ); film thickness 0.25 $\mu \mathrm{m}$. The operating conditions were as follows: carrier gas, hydrogen with a flow rate of $30 \mathrm{~mL} / \mathrm{min}$; column temperature, $80-220{ }^{\circ} \mathrm{C}$ at $4{ }^{\circ} \mathrm{C} / \mathrm{min}$.; injector and detector temperature, $250{ }^{\circ} \mathrm{C}$; volume injected, $0.2 \mu \mathrm{L}$ of the oil; split ratio, 1:150.

\section{Treatment}

Groups with 12 rats each were used. The animals were placed individually in acrylic boxes and treated as follows: different groups were exposed to the inhalation of OEO $1.0 \%, 2.5 \%$ and $5.0 \% \mathrm{w} / \mathrm{w}$ (experimental groups); control groups were exposed of saline, and one group received diazepam $1.5 \mathrm{mg} /$ $\mathrm{kg}$ i.p. All the procedures were carried out for $7 \mathrm{~min}$. immediately before the tests, as described by Almeida et al. (2004).

\section{Open-field behavioral test}

The open-field test was originally proposed as a measure of emotionality, with the animals being exposed to excessive light or noise. The rats were individually placed in the center of the open-field, which was circular, divided into 3 concentric circles subdivided by straight line segments into 19 equal parts measuring $80 \mathrm{~cm}$ of diameter and $30 \mathrm{~cm}$ of height. The lighting was equivalent to 3 light bulbs of 60 watts placed 100 $\mathrm{cm}$ above the floor of the open-field. We recorded the behavioral parameters regarding locomotion in the center of the arena and its peripheral walls; frequency of rearing (number of times the animals stood on their hind limbs), freezing (total motionless time) and the number of fecal boluses for $5 \mathrm{~min}$. (Candland and Campbell, 1962). In order to minimize the possible influence of circadian alterations, we observed the animals between 1:00 and 5:00 p.m.

\section{Social interaction test}

This procedure is based on the observation that animals tend to reduce or even suppress their interaction with other animals under conditions of new environments or excessive light. The device we used was the same as described above for the open-field behavioral test. Pairs of rats with up to $10 \mathrm{~g}$ difference in weight were placed in the center of the arena for us to quantify their activities of active social interaction: grooming, sniffing, biting or having a sexual behavior toward the other animal. We recorded the social interaction of the animals for 5 minutes between 1:00 and 5:00 p.m. as described by File and Hyde (1978), irrespectively of the place in the arena where the animals were. The device was washed 
with a $5 \%$ alcohol/water solution before we tested each pair in order to prevent possible bias to odor clues left by previous subjects.

\section{Elevated plus-maze test}

The maze consists of two open arms and two closed arms by $30 \mathrm{~cm}$ high walls. Each arm measures 50 $\mathrm{cm}$ of length by $10 \mathrm{~cm}$ of width and contains a central square of $10 \times 10 \mathrm{~cm}$. The maze was $60 \mathrm{~cm}$ above the floor. We placed the animals in the maze and recorded the number of times they entered the open and closed arms, as well as how long they stayed there within 5 min. In order to evaluate their level of emotionality, we considered their number of entries in the open arms and the time they remained there: the higher the number, the lower their level of emotionality (Pellow et al., 1985).

\section{Statistical analysis}

Student's t test was used to analyze the behavioral parameters observed in the open-field, as well as the one-way ANOVA, followed by the Tukey's and the Duncan's tests, to analyze the data we obtained in the TSI and the EPM, respectively. The level of significance was set at $5 \%$.

\section{RESULTS}

\section{Identification of constituents of OEO}

The chromatographic analysis of the OEO showed a phytochemical profile that confirms the presence of the main classes of components characteristic of the species Citrus aurantium L., namely: alphapinene $0.53 \%$; sabinene $0.27 \%$ myrcene $2.24 \%$; limonene $96.24 \%$; linalool $0.44 \%$; and decanal $0.25 \%$; (Figure 1).

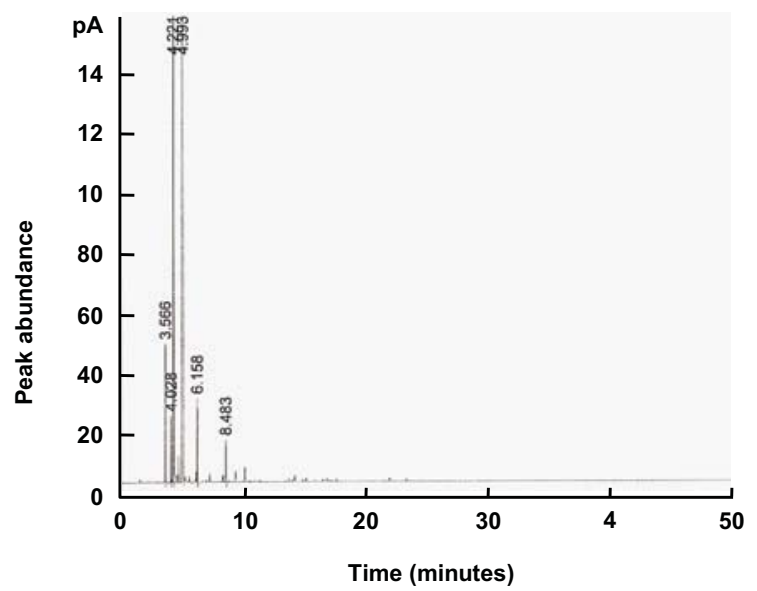

Figure 1. Gas chromatography retention times for the chemical components of the orange essential oil from Citrus aurantium L.

\section{Open-field behavioral test}

The animals previously exposed to the inhalation of OEO $2.5 \%$ and evaluated individually in the open-field showed a lower number of fecal boluses when compared with the animals in the control group $[F(1,18)=3.37, \mathrm{p}<0.05]$ but they did not differ regarding ambulation (Fig. 2A). The time of rearing or freezing were not changed (Figure 2B).
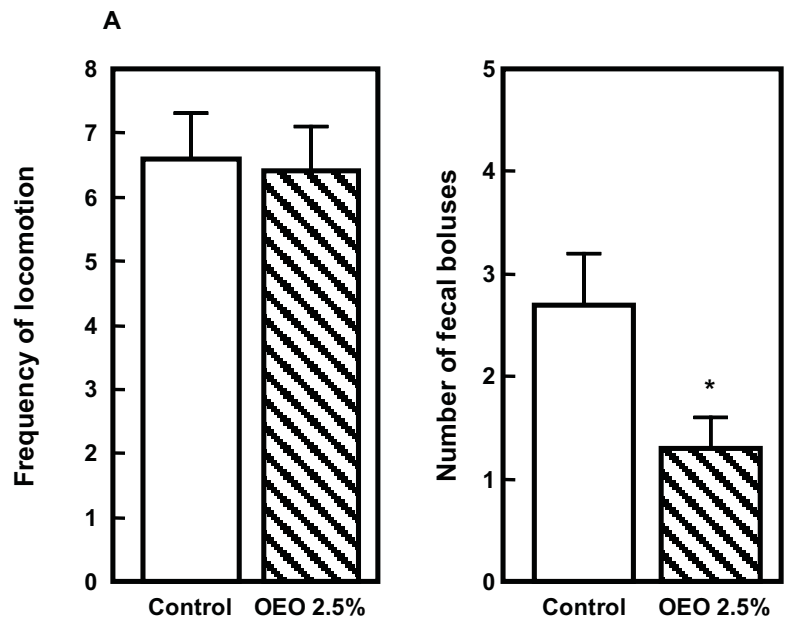

B

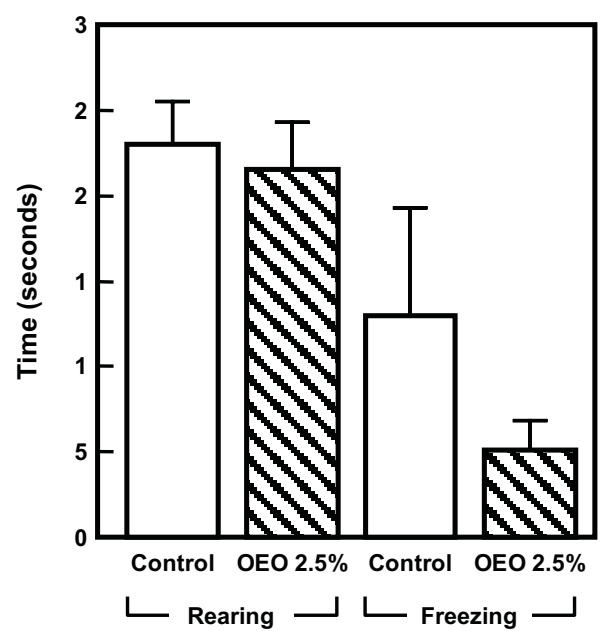

Figure 2. Effects of orange essential oil (inhalation route) on the frequency of locomotion, number of fecal boluses (A) and time spent in rearing and freezing $(\mathrm{B})$ of rats observed in the open-field. Data are reported as means \pm S.E.M. $(*) p<0.05$ compared to control group (Student's t test).

\section{Social interaction test}

The time of active social interaction of the animals exposed to the inhalation of OEO $2.5 \%$ showed statistically significant differences from the time of interaction of the control animals $[F(5,62), \mathrm{p}<0.005]$. This time difference was even greater than that between the animals in the OEO and the animals in the standard 
group that received diazepam (Figure 3).
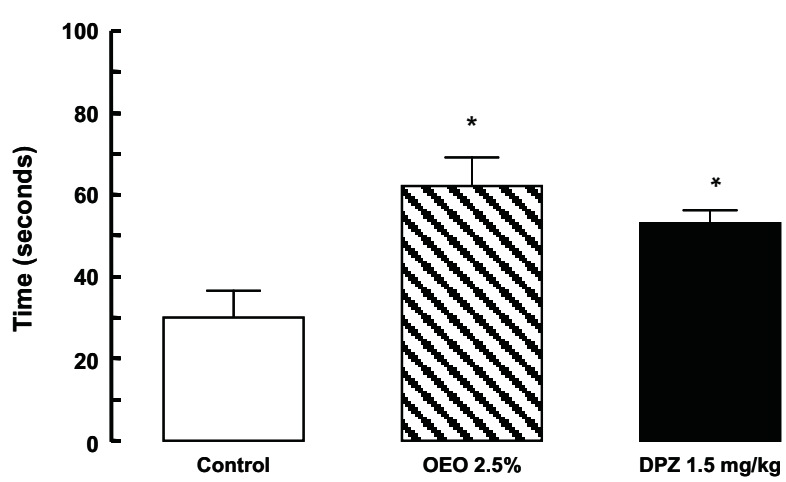

Figure 3. Time spent in active social interaction for pairs of rats after inhalation of orange essential oil or pairs of rats after diazepam administration (ip). $\mathrm{N}=12$ pairs per group. Data are reported as means \pm S.E.M. $(*) p<0.05$ compared to control group. (One-way analysis of variance (ANOVA) followed by Tukey's test).

\section{Elevated plus-maze test}

The data indicate that the numbers of entries into the open and closed arms in the EPM were not significantly changed by inhalation of OEO (Fig. 4A). On the other hand, the OEO 2.5\% induced a significant increase in the time of the animals remained in the open arms of the EPM $[F(12,103.48)=2.00, \mathrm{p}=0.03]$, as well as a trend towards a decrease in the time they stayed in the closed arms, when compared with the control animals (Figure $4 \mathrm{~B}$ ).

\section{DISCUSSION}

Essential oils, especially those of citrus fragrances, are popularly used as therapies for their effects on mood states and depression (Rovesti and Colombo, 1973; Agra et al., 2008), and the orange essential oil is believed to induce an effect of mental relaxation (Sugano and Sato, 1991). The results of our study suggest that the orange essential oil, at the concentration of $2.5 \%$, induced a decrease in the level of emotionality evaluated in two models of anxiety. Such response might be correlated with the activation of the olfactory system by the volatile components present in the oil, which suggests a possible central action. We should highlight the fact that anxiolytic drugs lessen fear and inhibit the exploratory activity of animals (Jones et al., 1992). Different studies point to a potential antidepressant effect in rats exposed to citrus fragrances (Komori et al., 1995b), as well as an anxiolytic effect in mice previously administered with OEO and evaluated in the EPM, an effect which is likely to be attributed to a specific component of the oil as the limonene, with a recognized antidepressant action on the central nervous system (Carvalho-Freitas and Costa, 2002). Similar results were obtained with rats previously exposed to

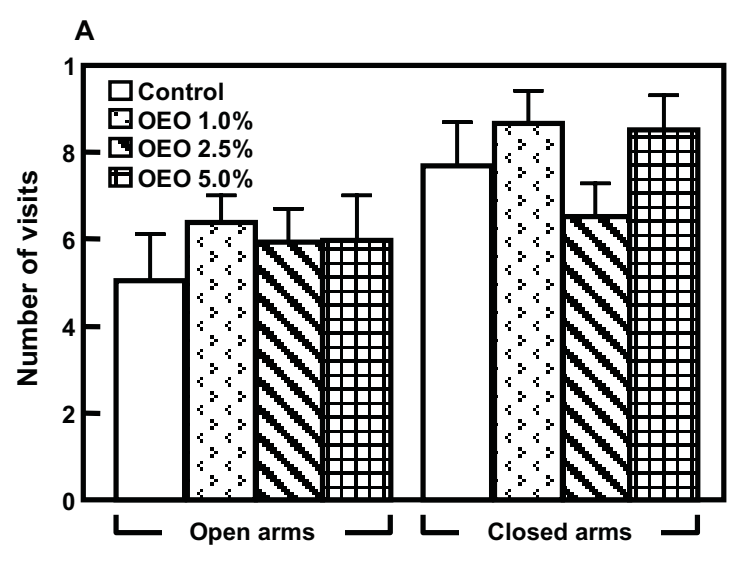

B

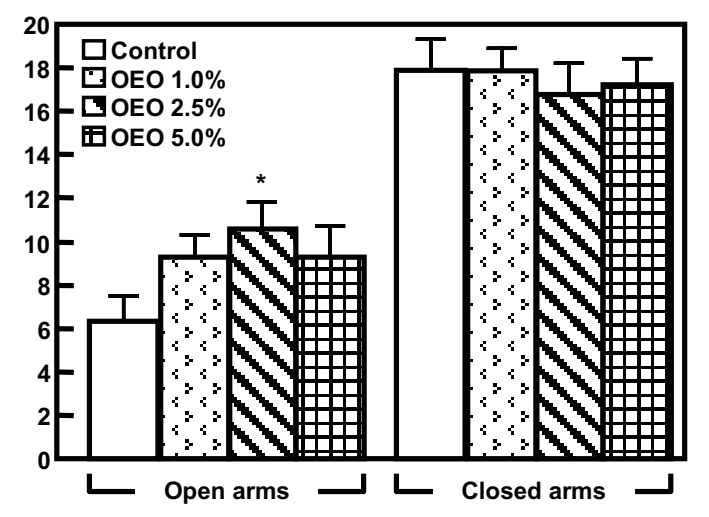

Figure 4. Effects of different concentrations of orange essential oil (inhalation route) on the number of entries in open and closed arms (A) and time spent in open and closed arms (B) of rats in the EPM. Data are reported as means \pm S.E.M. (*) $\mathrm{p}<0.05$ compared to control group. (One-way analysis of variance (ANOVA) followed by Duncan's test).

the inhalation of rose essential oil and submitted to the EPM, since it was observed an increase both in the number of times they entered the open arms and the time they remained there. The anxiolytic action was attributed to the presence of the components citronellol and 2-phenethyl alcohol (Almeida et al., 2004).

Considering that anxious rats do not socialize with one another, the results we obtained with the animals exposed to the inhalation of OEO $2.5 \%$ and evaluated in the open-field presented a longer time of active social interaction when compared with the animals in the control group. These results corroborate those obtained in the EPM. The anti-anxiety response should also be correlated with an action of the OEO on serotoninergic and/or GABA activity (Komiya et al., 2006). The decrease in the level of emotionality of the animals was also observed in the open-field evaluations, since they presented a decrease in the number of fecal droppings when compared with the animals in the control group. That response might be correlated with a low level of emotionality of the animals, since rats 
exposed to anxiogenic situations present a larger number of fecal droppings in the open-field (Pal et al., 2006). On the other hand, the OEO did not affect the sensorymotor function of the animals. There were no alterations in their general activity and exploratory ability, as both the rearing and freezing times remained the same as those in the control group. Our data are in line with the effects observed in a clinical study carried out with women exposed to an orange-scented environment. The subjects showed a decrease in their levels of anxietystate, a mood improvement and an increase in their levels of calmness, factors that were attributed to a possible behavioral and physiological effect (Lehrner et al., 2000). The scents of orange and lavender have the property to alter emotional states and reduce anxiety (Lehrner et al., 2005). In conclusion it has been shown that the exposure to the orange essential oil can actually contribute to the treatment of psychiatric disorders, as well as reduce psychological stress safely, without the typical adverse effects of conventional medications (Perry and Perry, 2006).

\section{ACKNOWLEDGMENTS}

The authors are grateful to Associação Fundo de Incentivo à Psicofarmacologia (AFIP) for the financial support.

\section{REFERENCES}

Agra MF, Silva KN, Basílio IJLD, França PF, Barbosa-Filho JM 2008. Survey of medicinal plants used in the region Northeast of Brazil. Rev Bras Farmacogn 18: 472-508

Almeida RN, Motta SC, Brito FC, Catallani B, Leite JR 2004. Anxiolytic like effects of rose oil inhalation on the elevated plus maze test in rats. Pharmacol Biochem Behav 77: 361-364.

Barbosa-Filho JM, Cunha RM, Dias CS, Athayde-Filho PF, Silva MS, Cunha EVL, Machado MIL, Craveiro AA, Medeiros IA 2008. GC-MS Analysis and cardiovascular activity of the essential oil of Ocotea duckei. Rev Bras Farmacogn 18: 37-41.

Candland DK, Campbell BA 1962. Development of fear in the rat as measured by behavior in the open-field. $J$ Comp Physiol Psychol 55: 593-596.

Carvalho-Freitas MIR, Costa M 2002. Anxiolytic and sedative effects of extracts and essential oil from Citrus aurantium L. Biol Pharm Bull 25: 1629-1633.

De-Souza MM, Garbeloto M, Denez K, Eger-Mangrich I 2006. Avaliação dos efeitos centrais dos florais de Bach em camundongos através de modelos farmacológicos específicos. Rev Bras Farmacogn 16: 365-371.

Ferronatto R, Marchesan ED, Pezenti E, Bednarski F, Onofre SB 2007. Atividade antimicrobiana de óleos essenciais produzidos por Baccharis dracunculifolia D.C. e Baccharis uncinella D.C. (Asteraceae). Rev Bras Farmacogn 17: 224-230.

File SE, Hyde JR 1978. Can social interaction be used to measure anxiety? Brit J Pharmacol 62: 19-24.
Gumnick JK, Nemeroff CB 2000. Problems with currently available antidepressants. J Clin Psychiatry 61: 5-15.

Hwang JH 2006. The effects of the inhalation method using essential oils on blood pressure and stress responses of clients with essential hypertension. Taehan Kanho Hakhoe Chi 36: 1123-1134.

Jones GH, Hernandez ID, Kendall DA 1992. Dopaminergic and serotonergic function following isolation rearing in rats: study of behavioural responses and postmortem and in vivo neurochemistry. Pharmacol Biochem Behav 43: 17-35.

Komori T, Fujiwara R, Tanida M, Nomura J 1995a. Effects of citrus fragrance on immune function and depressive state. Neuroimunomodulat 2: 174-180.

Komori T, Fujiwara R, Tanida M, Nomura J 1995b. Potential antidepressant effects of lemon odor in rats. Eur Neuropsychopharmacol 5: 477-480.

Komiya M, Takashi T, Harada E 2006. Lemon oil vapor causes an anti-stress effect via modulating the 5-HT and DA activities in mice. Behav Brain Res 172: 240-249.

Lehrner J, Eckersberger C, Walla P, Pötsch G, Deecke L 2000. Ambient odor of orange in a dental office reduces anxiety and improves mood in female patients. Physiol Behav 71: 83-86.

Lehrner J, Marwinski G, Lehr S, Johren P, Deecke L 2005. Ambient odor of orange and lavender reduce anxiety and improve mood in a dental office. Physiol Behav 86: 92-95.

Oliveira RAG, Lima EO, Vieira WL, Freire KRL, Trajano VN, Lima, IO, Souza EL, Toledo MS, Silva-Filho RN 2006. Estudo da interferência de óleos essenciais sobre a atividade de alguns antibióticos usados na clínica. Rev Bras Farmacogn 16: 77-82.

Oliveira RAG, Lima EO, Souza EL, Vieira WL, Freire KRL, Trajano VN, Lima IO, Silva-Filho RN 2007. Interference of Plectranthus amboinicus (Lour.) Spreng essential oil on the anti-Candida activity of some clinically used antifungals. Rev Bras Farmacogn 17: 186-190.

Pal R, Gulati K, Chakraborti A, Banerjee B, Ray A 2006. Role of free radicals in stress-induced neurobehavioral changes in rats. Indian J Exp Biol 44: 816-820.

Pellow S, Chopin SE, File SE, Briley M 1985. Validation of open closed arm entries in an elevated plus maze as a measure of anxiety in the rat. $J$ Neurosci Methods 14: 140-167.

Perry N, Perry E 2006. Aromatherapy in the management of psychiatric disorders: clinical and neuropharmacological perspectives. CNS Drugs 20: 257-280.

Pollatos O, Albrecht J, Kopietz R, Linn J, Schoepf V, Kleemann AM, Schreder T, Schandry R, Wiesmann M 2007. Reduced olfactory sensitivity in subjects with depressive symptoms. J Affect Disord 102: 101108.

Pultrini AM, Galindo LA, Costa M 2006. Effects of the essential oil from Citrus aurantium L. in experimental anxiety models in mice. Life Sci 78: 1720-1725.

Rovesti P, Colombo E 1973. Aromatherapy and aerosols. Soap Parfum Cosmet 46: 475-477.

Sousa DP, Nóbrega FFF, Claudino FS, Almeida RN, Leite JR, Mattei R 2007. Pharmacological effects of the 
monoterpene $\alpha, \beta$-epoxy-carvone in mice. Rev Bras Farmacogn 17: 170-175.

Sousa PJC, Barros CAL, Rocha JCS, Lira DS, Monteiro GM, Maia JGS 2008. Avaliação toxicológica do óleo essencial de Piper aduncum L. Rev Bras Farmacogn 18: 217-221

Sugano H, Sato H 1991. Phychophysiological studies of fragrance. Chem Senses 16: 183-184.

Umezu T, Ito H, Nagano K, Yamakoshi M, Oouchi H, Sakaniwa M, Morita M 2002. Anticonflict effects of rose oil and identification of its active constituents. Life Sci 72: 91-102.

Van Toller S 1988. Emotion and the brain. In: Van Toller, S. and Dodd, G.H. The Psychology and Biology of Fragrance. Chapman \& Hall, London, p.121.

Viana GSD, Vale TG, Silva CMM, Matos FJD 2000. Anticonvulsant activity of essential oils and active principles from chemotypes of Lippia alba (Mill.) Ne Brown. Biol Pharm Bull 23: 1314-1317. 